NBER WORKING PAPER SERIES

\title{
HOW "ORIGINAL SIN" WAS OVERCOME: \\ THE EVOLUTION OF EXTERNAL DEBT DENOMINATED IN DOMESTIC CURRENCIES IN THE UNITED STATES \\ AND THE BRITISH DOMINIONS 1800-2000
}

\author{
Michael D. Bordo \\ Christopher Meissner \\ Angela Redish \\ Working Paper 9841 \\ http://www.nber.org/papers/w9841 \\ NATIONAL BUREAU OF ECONOMIC RESEARCH \\ 1050 Massachusetts Avenue \\ Cambridge, MA 02138 \\ July 2003
}

For helpful comments on earlier drafts we thank Pierre Duguay, Barry Eichengreen, Chuck Freedman, Ricardo Hausmann, Jorge Braga de Macedo, Peter Rousseau, Alan Taylor and participants at the Preconference at the Kennedy School of Government and the conference at the IADB. For valuable research assistance we thank: Antonio David, Sonal Dhingra and Nicholas Vrousalis. For financial support we thank the National Science Foundation and the UK Economics and Social Science Research Council. The views expressed herein are those of the authors and not necessarily those of the National Bureau of Economic Research

(C)2003 by Michael D. Bordo, Christopher Meissner, and Angela Redish. All rights reserved. Short sections of text not to exceed two paragraphs, may be quoted without explicit permission provided that full credit including (C) notice, is given to the source. 
How “Original Sin" was Overcome: The Evolution of External Debt Denominated in Domestic

Currencies in the United States and the British Dominions, 1800-2000

Michael D. Bordo, Christopher Meissner, and Angela Redish

NBER Working Paper No. 9841

July 2003

JEL No. N20, F33

\section{ABSTRACT}

Many emerging countries today have difficulty in borrowing domestically long-term and are unable to borrow abroad (both sovereign and corporate debt) in terms of their own currencies. Consequently they need to borrow in dollars to access foreign capital markets. This problem of "“'Original Sin"” also plagued many of the emerging countries in the previous age of financial globalization, the half century preceding World War I.

This paper examines the issue of "Original Sin" from a historical perspective. We provide answers to a number of questions including: what factors determine membership in the club of countries who are free from Original Sin? What can countries do to enter this club? Is entry permanent or transitory? Under what circumstances does entry occur - in the face of big shocks like World War I or as part of a gradual evolution? Did countries free themselves from one component of Original Sin (e.g., by lengthening domestic debt maturity) but not the other? Finally, does the fact a country has little external debt in terms of its own currency necessarily make it vulnerable to crises because of a currency mismatch?

This paper attempts to provide some answers to these questions by conducting an historical case study for a group of countries that successfully entered the club and had largely overcome the problem of Original Sin by the third quarter of the twentieth century. The group consists of several former colonies of Great Britain: the United States, Canada, Australia, New Zealand and South Africa. We trace out their debt history relating the currency to the place of issue, exploring the residency of those holding local and foreign currency debt and looking at the maturity of domestic debt in the nineteenth and twentieth centuries.

We find that sound fiscal institutions, high credibility of the monetary regime and good financial development are not sufficient to completely break free from Original Sin. Conversely, poor performance in these policy realms is not, for the most part, a necessary condition for Original Sin. The factor we emphasize for the common movements across the five countries is the role of shocks such as wars, massive economic disruption and the emergence of global markets. The differences in evolution between the U.S. and the Dominions we attribute to differences in size, the traits of a key currency, which the U.S. possessed and the others did not, and to membership in the British Empire. The important role of major shocks suggests that the establishment of a bond market involved significant start-up costs, while the role of scale suggests that network externalities and liquidity were pivotal in the existence of overseas markets in domestic currency debt.

Michael D. Bordo
Department of Economics
Rutgers University
75 Hamilton Street
New Brunswick, NJ 08901
and NBER
bordo@econ.rutgers.edu

Christopher Meissner

Kings College and University of Cambridge Faculty of Economics and Politics Austin Robinson Building

Sidgewick Avenue Cambridge CB3 9DD England and NBER Christopher.m.meissner@econ.cam.ac.uk
Angela Redish Department of Economics University of British Columbia Vancouver, B.C. Canada V6T 1Z1 anji@econ.ubc.edu 


\section{Introduction}

The recent spate of emerging market crises in Asia has focused attention on balance sheet problems as a key source of instability (Larain and Velasco 2001). Many emerging countries today have difficulty in borrowing domestically long-term and are unable to borrow abroad (both sovereign and corporate debt) in terms of their own currencies. Consequently they need to borrow in dollars to access foreign capital markets. As discussed in several papers in this volume, this state of affairs is often attributed to the absence of sound and credible fiscal and monetary policy and financial underdevelopment.

In the face of a currency crisis, a depreciating domestic currency leads to insolvency as firms and governments are unable to service their dollar debts. In addition the inability to rollover short-term debt increases the prospects for default. Eichengreen and Hausmann (1999) refer to the inability to borrow abroad in terms of domestic currency and to borrow domestically long-term as "Original Sin". Some solutions to the problem they posit are to attain the financial maturity and fiscal probity required to have a nation's debt denominated in domestic currency, the imposition of capital controls, dollarization or a currency union with an advanced country. In this volume Eichengreen, Hausmann, and Panizza highlight the role of international institutions in creating new markets.

The problem of Original Sin also plagued many of the emerging countries in the previous age of financial globalization, the half century preceding World War I. In that era, the peripheral countries of Europe, the Americas and elsewhere had to borrow in Sterling (or francs or guilders) denominated bonds or else have gold clauses in order to 
access loans from London (Paris or Amsterdam). The gold clauses protected the lender against currency risk. They also may have served as a commitment mechanism (Bordo and Flandreau 2003).

In sharp contrast to the emerging countries' experience, a select number of countries today and in the past did not have the currency mismatch problem. These countries are able to issue debt in their own currency abroad and their domestically issued domestic currency debt is readily traded and held on foreign markets. Selling long-term domestic debt is not impossible. This also was the case for a number of advanced countries before 1914. Eight advanced countries had their bonds listed on the London Stock Exchange in their own currencies - the U.K., France, Netherlands, Belgium, the United States, Germany, Denmark and Switzerland (Bordo and Flandreau 2003) ${ }^{1}$. Today the list has expanded to 25 countries most of which are in the OECD, with the peripheral additions of South Africa, Hong Kong and Singapore.

A number of questions arise from this evidence including: what factors determine membership in the club of countries who are free from Original Sin? What can countries do to enter this club? Is entry permanent or transitory? Under what circumstances does entry occur - in the face of big shocks like World War I or as part of a gradual evolution? Did countries free themselves from one component of Original Sin (e.g., by lengthening domestic debt maturity) but not the other? Finally, does the fact a country has little external debt in terms of its own currency necessarily make it vulnerable to crises because of a currency mismatch?

\footnotetext{
${ }^{1}$ Although, according to Flandreau and Sussman (this volume ) two of these (France and Denmark.) had gold clauses on their debt during certain periods. They also include Austria, Italy, Russia and Spain in a group that had some amount of bonds listed in their own currencies on London and Paris. The U.S. as we discuss below usually had some form of coin and gold clause.
} 
This paper attempts to provide some answers to these questions by conducting an historical case study for a group of countries that successfully entered the club and had largely overcome the problem of Original Sin by the third quarter of the twentieth century. The group consists of several former colonies of Great Britain: the United States, Canada, Australia, New Zealand and South Africa. We trace out their debt history relating the currency to the place of issue, exploring the residency of those holding local and foreign currency debt and looking at the maturity of domestic debt in the nineteenth and twentieth centuries.

We treat the United States separately (in section 2) from the former Dominions (section 3) because its experience differed considerably from the common experience of the other four countries. The U.S. government was able to issue and market small amounts of dollar bonds abroad by the beginning of the nineteenth century. For the most part, U.S. sovereign debt had implicit or explicit gold clauses until 1933. States and corporations only completely borrowed in dollars by the late nineteenth century and always did so with gold clauses until the gold standard was finally abandoned under Roosevelt. The U.S. never had a serious problem issuing debt long-term.

The Dominions largely shifted to domestic currency external sovereign debt after 1973; Canada was the leader so that by the 1950s non-residents were willing to hold the majority of their Canadian debt in local currency. Previously these Dominions had borrowed in Sterling and U.S. dollars. However all these countries issued significant amounts of domestic debt in terms of their own currencies by the 1920s and their reliance on external debt therefore was quite limited. Finally, like the U.S., the Dominions rarely had difficulty in issuing long-term debt. 
In section 4, we consider the factors that may explain the evolution of the U.S. and the Dominions to a state free of Original Sin. We find that sound fiscal institutions, high credibility of the monetary regime and good financial development are not sufficient to completely break free from Original Sin. Conversely, poor performance in these policy realms is not, for the most part, a necessary condition for Original Sin. The factor we emphasize for the common movements across the five countries is the role of shocks such as wars, massive economic disruption and the emergence of global markets. The differences in evolution between the U.S. and the Dominions we attribute to differences in size, the traits of a key currency, which the U.S. possessed and the others did not, and to membership in the British Empire. The important role of major shocks suggests that the establishment of a bond market involved significant start-up costs, while the role of scale suggests that network externalities and liquidity were pivotal in the existence of overseas markets in domestic currency debt.

Section 5 concludes with the insight that although none of these countries really was completely free from Original Sin in the nineteenth century in both the senses stressed by Eichengreen and Haussman, they really were not vulnerable to the types of risk-creating financial crises that face today's emergers. Our five countries had all developed institutions by the mid twentieth century which greatly reduced their vulnerability. 


\section{The United States}

Today the United States is home to the world's largest financial center. Debt is mainly issued at home in dollars by domestic players. Dollar assets issued by U.S. entities are readily held abroad. Nearly all other countries issue some liabilities in U.S. dollars as well. Below we document the evolution of the main aspects of Original Sin: ability to issue debt abroad in domestic currency; the incidence of non-resident holdings of domestic currency debt; and the maturity of domestic debt.

The US government issued foreign currency debt in the early years after the revolution, but paid it off relatively quickly, and subsequently never issued debt in foreign currencies. However, legal tender laws that made only gold and silver coin legal tender meant that there were implicit specie clauses in dollar denominated debt issues as was the case in virtually all countries adhering to the gold standard. The issue of Greenbacks during the Civil War led creditors to put explicit gold clauses in their bonds, until the Federal government invalidated such clauses in 1933. Thus after 1933, US dollar debt was free of any implicit or explicit gold-indexing or fixed exchange rate clauses. Foreign willingness to hold these domestic currency assets free from any fixed constraints has no doubt increased since the 1930s.

Evidence on maturities shows that private companies, like the federal and state governments have issued debt long-term domestically since the 1780s. The U.S. has certainly graduated from Original Sin. The question is when did it do so? 


\section{Federal Government}

Until the early part of the 1790s, American finances were in a shambles. The issue of paper currency (the "continentals") to finance the Revolutionary war led to high inflation and extensive depreciation of the American currency. By the end of the Revolutionary war, the U.S. position in terms of debt to revenues ranked among the worst of the sovereigns in Europe - comparable to Spain, the Kingdom of Poland and lesser German states.

Dutch financing helped the country out early on. One of the first foreign loans the U.S. placed was backed by France and sold in Amsterdam. Thus much of the early public debt during and after the American Revolution was denominated in Dutch florins and issued in Holland.

The U.S. increasingly relied on domestic dollar loans with gold clauses beginning in the 1780s but Alexander Hamilton's funding plan, part of a comprehensive financial package set the stage for the successful issuance of dollar denominated debt. Hamilton's funding plan created approximately $\$ 65$ million in domestic debt, and at the same time provided for borrowing of $\$ 12$ million in Dutch florins. In the event, only $\$ 8$ million in Dutch bonds were issued, and they were paid off, according to schedule, between 1800 and 1810. These were the last foreign currency denominated bonds issued by the U.S. until the late $20^{\text {th }}$ century.

Foreign currency denominated debt outstanding had become a relic by the time of the Louisiana Purchase in 1803 (Tables 1 and 2). ${ }^{2}$ Over the period 1803 to 1853 the fraction of public debt held abroad declined somewhat (see Table 3). By this time

\footnotetext{
${ }^{2}$ Debt issued abroad for this transaction was denominated in dollars but lenders had the option of repayment at the rate of $£ 1 \mathrm{stg}=\$ 4.44$ or one French franc for each $\$ 0.40$ issued.
} 
whatever was held abroad was dollar denominated. This debt, which was issued primarily domestically, promised implicitly rather than explicitly to pay in specie as far as we can tell. $^{3}$

In the early years of the country there is no evidence of short maturity structures at the federal level. We have data from Elliot (1968) on new issues between 1790 and 1843 . Nearly all new issues up to about 1805 were payable 'at the pleasure of the United States,' and no new issue had a maturity of less than eight years. During periods of turmoil we do see maturities decline from these high levels. Some other evidence also suggests a slight relapse into sin. In 1841 and coming on the heels of international defaults by eight states, the first subsequent federal issue had a maturity of four years. This did not last long. Issues in 1842 and 1843 fell due in 21 and 10 years respectively.

\section{From the Civil War to World War I}

The United States suspended specie convertibility during the Civil War in January 1862 and did not resume until January 1879. 'Greenbacks' or federal legal tender fiat money operated as de facto fiat currency for the entire period throughout most of the U.S. with the principal exception of California where gold coin and gold backed notes circulated.

During the Civil War, the Union increased its debt by 30 times and the debt to GDP ratio reached nearly 50 percent. Most of this debt was issued at home. Wilkins

\footnotetext{
3 A note from Levi Woodbury, in 1840 suggests that the Treasury had always paid "in specie or its equivalent" prior to the 1830s. (The Funding System of the United States and of Great Britain p.969). In fact Hamilton's Funding Plan was predicated on the appropriation of funds collected from tariffs and land sales both of which would have been in specie. Still, a joint resolution of congress in 1816 apparently
} 
suggests that only about ten percent of the Union debt ended up being held in Europe by 1864.

Despite the increase in the debt burden, the government continued to pay nearly all of its interest payments in gold at the historical parity. But investors faced uncertainty since the legislation stating the method of paying interest and principal on loans fluctuated (Dewey, 1920). Often it was unclear whether principal and interest would be repaid in paper or specie. From 1870 until about 1900 it was uncertain if interest and principal would be paid in gold or in silver. ${ }^{4}$

Exceptionally, the Loan Act of 1861 made no mention of how interest and principal would be paid. This debt, about $1 \%$ of the overall debt was effectively payable in the fiat currency of the time (Friedman and Schwartz p.27). How much of this was held abroad is unknown. ${ }^{5}$

Debt authorizations between 1862 and March 1864 stated that interest and principal were to be paid "in coin". The government declared in June 1864 that interest was to be paid in coin but made no explicit statement on principal, and the issue of 3 March 1865 echoed this. Other issues had explicit gold clauses on the interest payments and left out any information on how the principal would be re-paid. Later issues declared interest and principal would be re-paid in the coin standard of the United States of

relaxed the legal constraint and allowed for notes of specie paying banks to be accepted for payment at the Treasury and hence may have been used to pay some interest payments.

${ }_{5}^{4}$ Silver had been secularly depreciating against gold since 1873 .

${ }^{5}$ By 1880 the outstanding U.S. federal debt included $\$ 1.17$ billion in registered bonds and $\$ 537$ million in coupon bonds. All were in U.S. dollars with the above stipulations. A Congressional investigation concluded (by looking at the domicile of the registered bonds and asking the large New York banks where the coupons they were surrendering came from) that about $\$ 250$ million - or 14 percent - were held by foreigners. 
America. This variety of wording continued to be common until the late nineteenth century.

To reassure markets, Congress approved "An Act to Strengthen the Public Credit" in March 1869. The act declared the American commitment to re-pay the principal of all outstanding debt in coin at a fixed rate. Again, in 1870, funding acts that authorized bond issues underscored the desire of the United States to repay all debt in legal tender coin of the country by stating that bonds were "redeemable at the pleasure of the United States...in coin of the standard value of the United States on said July $14^{\text {th }}$, 1870 with interest in such coin, from the day of their date...". ${ }^{6}$ Unfortunately, the inherent ambiguity of the 'in coin' clause (see Table 4) and of not explicitly stating that debt was payable in gold would haunt the U.S. until the 1890s.

Despite these ambiguities, creditors (a minority of them foreigners) accepted Federal debt in the domestic currency of the U.S. whatever form it took. In fact after silverites convinced congress to remove the gold clause from an 1895 issue instead inserting a specie clause, these bonds were successfully sold abroad (principally London) but with a face value interest rate of 4 percent rather than the 3 percent a gold bond would have carried.

Doubt about the exchange rate regime was laid to rest in 1899 when the U.S. enacted a law declaring gold to be the exclusive currency of the U.S. This led to the Gold Standard Act of 1900 which put the U.S. firmly on the gold standard. This and other propitious economic events allowed the U.S. to avoid further misunderstandings about how debt would be repaid and how it should be denominated. In any case, the U.S. did

\footnotetext{
${ }^{6}$ Curiously the original proposal was to sell debt abroad that would be payable in sterling, francs and thalers. Congress rejected this idea immediately leaving the U.S. to denominate its debt in dollars while paying at a fixed rate in terms of gold (see Wilkins (1989; n.154, 681).
} 
not make too many new issues on foreign markets for a period after 1899 , and the amount of federal debt held in foreign hands is said to have declined quite rapidly after 1899 (Wilkins 1989). As most federal debt came to be issued and held domestically the currency denomination aspect of Original Sin became less important. ${ }^{7}$

\section{The Interwar Period and the Great Depression}

From the Civil War period until the abrogation of the gold clauses under Roosevelt in 1933 virtually all federal bonds carried a gold clause (Kroszner 1999). Still, debt was exclusively denominated in dollars, and after the devaluation, debt was in fact re-paid in notes at the depreciated rate. To the extent that creditors could foresee such an outcome and had been willing to take this risk upon purchase, the U.S. had partially graduated from Original Sin. After this, the U.S. never returned to issuing significant amounts of bonds with gold clauses. We view this as the moment when the country completely and definitively broke free from Original $\mathrm{Sin}^{8}$

\section{World War II to the Present}

After World War II, the U.S. continued to issue debt almost exclusively in domestic currency. Particularly in the 1970s, considerable amounts of this debt were held as

\footnotetext{
${ }^{7}$ The U.S. went to the London Stock Exchange for 4 issues of debt in 1880 and 2 in 1900, but made 15 and 11 issues in New York during the respective years (Davis and Cull, 1994 p. 67).

${ }^{8}$ The maturity structure of the debt reveals no lack of confidence; maturities were on the order of five to 40 years prior to 1913. Maturities on new issues of bonds did fall quite precipitously about 1931 with the deepening of the Great Depression, but they apparently recovered by around 1935. Data from the Financial Chronicle lists all new issues for each of the four years between 1932 and 1935, and suggests that the average maturity was $2.56,4.9,5.8$ and 12.3 in each successive year after 1932. Still, the weighted average of all outstanding debt between 1932 and 1935 was respectively, 12.2, 11.5, 11.8 and 15.3 years.
} 
official reserves by foreign governments. More recently private sector agents hold most of the foreign held debt.

The most noteworthy foray into the issue of foreign currency denominated debt was the Roosa bonds issued in the 1960s. These bonds, denominated in the principal European currencies were an attempt by the Treasury to stem the ongoing gold drain that dominated the Bretton Woods period. However, these bonds were issued in very limited amounts. Similar bonds were issued in the 1970s and were referred to as Carter bonds.

The federal government has also maintained the ability to borrow long-term. Average maturities on the funded debt outstanding rose from about 9.2 years in 1966 to 21.5 years (Monthly Statement of the Public Debt Outstanding). One should also note however, that the funded debt as a proportion of the total marketable debt outstanding fell from about one-half in 1966 to one-fifth in 1985 and one-sixth in 1996.

\section{States}

State debt issues swamped federal government debt issues in terms of total amounts outstanding by the mid-nineteenth century. The States' probity was more tainted than the federal government's. Repudiations and defaults occurred first in the 1840s, then after the Civil War in the former confederate states and again in the 1870s. This eventually led the states to impose their own limits on borrowing. The effect was also to essentially curtail their ability to issue on foreign markets by the opening of the $20^{\text {th }}$ century (Wilkins 1989). Like the federal government, state issues carried explicit gold clauses from the Civil War until 1933.

States issued securities at home and abroad in the early nineteenth century for the purpose of building infrastructure and chartering state banks. Domestic issues which 
American and British banks often eventually placed abroad were denominated in dollars with gold clauses or fixed exchange rate clauses. At other times they were simply denominated in pounds with a fixed exchange rate clause. Early foreign issues tended to be denominated in pounds sterling or other foreign currencies (Ratchford 1941). The success of these issues led dollar-denominated securities with gold clauses which were issued in the U.S. to be transferred abroad by the 1840s. In addition it appears that most bonds were long-term-on the order of nine to ten year maturities or longer. The fact that not all issues were in dollars, particularly those made abroad suggests that the U.S. states were not free from Original Sin prior to 1840.

After a wave of defaults in the early 1840s, states began to borrow afresh in the late 1840s. In the 1840s and 1850s it is said that not more than about 20 percent of all state debt was held abroad. Most of this was issued domestically and it is likely to have been dollar denominated with fixed exchange rate clauses or gold clauses. Ratchford (1941) claims that maturities on most state bonds were 30 to 40 years.

During the Civil War northern states issued mainly domestically. Massachusetts was an exception having nearly \$2 million of sterling bounty bonds outstanding by 1866 . The union states' original bonds required repayment in specie, but Ohio for example stopped paying in gold by 1863 . If we believe Ratchford's characterization of bonds during the Antebellum period, then maturities had fallen during the war. At this time they averaged nearly 20 years.

Southern states also tended to issue bonds at home, and made only a few attempts to take loans in London. When they did so the bonds often specified repayment in tradable goods such as cotton. Near the end of the war, most financing in the South was 
done through emissions of unfunded debt. Maturities on the funded debt were shorter than in the North and were about ten to twenty years.

Up to 1913 new state loans abroad were rare (Wilkins, 1989 p. 187). Uncertainty over the ability to service debt due to earlier defaults and the demand created by banking regulation in the U.S. led there to be only two state bonds listed in London in 1899

(Wilkins 1989). Of two loans issued by Massachusetts on London in 1896 both were gold bonds.

After World War I we have examined the Investor's Review from London and have not been able to find any new issues abroad of states debts. It is of course possible that foreigners came to hold debts through the course of trade or by purchasing them in New York but we have been unable to locate any data on foreign holdings. What we do know is that nearly all varieties of American debt continued to carry specie clauses until 1933 as Kroszner (1999) suggests. After this states are likely to have issued mainly on domestic markets. These would have to have been without gold clauses since these were banned by law. ${ }^{9}$

In terms of maturities, Ratchford reports that the median time until maturity of bonds between 1919 and 1938 was 15 to 20 years. Figure 1 taken from this source also shows the percentage of debt maturing between 3.1 and 5 years was always very low. ${ }^{10}$ Interestingly this percentage increases dramatically during the Great Depression.

\footnotetext{
${ }^{9}$ However, we have seen no evidence on the level of foreign holdings of these bonds during this period.

${ }^{10}$ Ratchford's figures imply that either no debt was outstanding with maturities of less than 3.1 years or he has simply disregarded this bunch of debt. The former is more likely the correct interpretation.
} 


\section{Private Companies}

Foreign investment in the United States has a long history. Most notable was the massive influx of British and European portfolio capital during the nineteenth century. Railroads were often the most sought after bonds and they took the lion's share of incoming capital, but investments went to other sectors as well. It is difficult to estimate how much of all outstanding debt foreigners held at any one time. Sparse data exist on the numerator and the denominator but not usually for the same years. In any case, it does not appear that any significant graduation from Original Sin came until the forced elimination of the gold clauses in 1933. Moreover, reliance on foreign capital markets was diminished---at least for the early years of the Bretton Woods period.

The use of foreign markets and sterling debt began in the 1850s when railroads first issued abroad. Later issues that were in dollars carried gold clauses. As late as the 1890s, American companies issued bonds on London both in sterling and in dollars as Table 5 shows. During and after the First World War, U.S. companies tended to issue mainly in New York as European capital markets were perturbed and New York's prominence was rising. Nearly all long-term corporate debt outstanding in the 1930s carried gold clauses (Kroszner 1999). After 1933 companies could not issue gold indexed debt by law in the U.S. Reliance on foreign markets also remained low immediately following World War II. Hence in the corporate sector, American companies have been relatively free of Original Sin since at least the mid-1930s. 


\section{Summary}

The United States is a special case amongst our countries. Since the 1850 s all players in the economy were able to issue debt denominated in U.S. dollars (with implicit or explicit gold or specie clauses) that non-residents were willing to hold. The U.S. maintained specie clauses, and this largely meant hard currency repayments ex post. Because there may have been a probability that foreign creditors would be paid in paper or depreciated silver we view this as an intermediate case. Only after 1933 did the U.S. federal government issue a significant amount of debt with no gold clause.

In the second meaning of Original Sin -- the maturity of debt -- we do see fluctuations that tend to suggest financial turmoil can put players on a shorter string. However average maturities on funded debt and corporate paper have always been long by today's LDC standards.

The U.S. graduated from Original Sin for the most part behind the curtain of a number of large successive shocks including the fiscal retrenchment after the Revolution, the Great Depression, World War II, and the Bretton Woods era. By the 1930s the U.S. had largely purged itself of Original Sin. We examine the determinants of this transition more in Section 4.

\section{The British Dominions.}

This section discusses the debt history of Canada, Australia, New Zealand and South Africa, four settler economies that emerged from British colonies. Despite some idiosyncratic variations, the experience of these countries was remarkably similar: in the $19^{\text {th }}$ and early $20^{\text {th }}$ century they borrowed in London in sterling, but during World War I 
they were cut off from the London market and developed domestic markets where they issued relatively long term domestic currency denominated debt. In the interwar period, Australia and Canada issued in New York (U.S. dollar denominated debt) but as many authors have noted, international capital flows remained small from World War I until the 1990s. Only in the last part of the $20^{\text {th }}$ century, did these four economies begin to issue debt overseas in their own currency. The evidence on non-resident holdings of domestically issued debt is murky, but in Canada, a leader amongst these four, we find that there are significant foreign holdings of local currency debt by the 1950s.

Thus far the story sounds as though the economies indeed suffered from Original Sin, and did so until very recently. As we show the story is more complex. First, at all times, the maturity of the debt outstanding - the foreign currency/foreign issued debt and the domestic currency/domestically issued debt - was long relative to to-day's standards. Second, with the possible exception of the $19^{\text {th }}$ century experience, there were large and liquid domestic currency debt markets.

\section{Pre World War I}

In the prewar period, governments borrowed primarily to finance infrastructure improvements. ${ }^{11}$ The data are most complete for Canada and show that over the period 1867 to 1914 , over 90 percent of the funded debt outstanding was in the form of sterling liabilities (see Figure 2). ${ }^{12}$ For the other colonies, the range was slightly lower (from 70 percent in Australia to 90 percent in New Zealand), but the bulk of borrowing was in the

\footnotetext{
${ }^{11}$ We discuss here sovereign debt since we lack data on local government and private sector debts.

${ }^{12}$ Canadian data for the period 1867 to 1900 are from the Public Accounts, 1950/1, which lists debts owing in London and New York, with the implication that the debt is denominated in the place of issue. For the period 1900-2001 the data on unmatured federal debt are from CANSIM II series V151538, and for unmatured debt in foreign currency they are series V151547.
} 
London market in all cases. Strikingly, there was a one-to-one correspondence between place of issue and denomination - this was sterling debt issued in London.

The loans tended to be quite long term, 10 to 25 years, and the governments were aware of the benefits of these maturities. For example, in 1912 the Canadian Minister of Finance took comfort in the fact that only 2 issues would come due before 1930 (Field, $1914 ; 104)$.

\section{From World War I to 1939}

The onset of World War I essentially closed the London capital market, and the response was similar in all four Dominions. The gold convertibility of the domestic currency was suspended (and not resumed until 1925) and governments raised funds domestically, essentially creating a domestic bond market with the aid of the commercial banks. Thus in Canada the government maintained a low interest peg on its securities which were largely absorbed and marketed to the public by chartered banks. Foreign issues relative to domestic issues (at least for sovereign debt) would never regain their earlier dominance. Figure 2 shows the decrease in the share of outstanding debt issued overseas. (The very dramatic nature of the declines reflects the quick expansion of domestically issued debt to finance the war efforts.) In Canada the Victory Loans, although issued in Canadian dollars, had explicit gold clauses.

Each country followed slightly different policies in the interwar period and had different experiences during the Depression. Canada raised funds in New York in U.S. dollars in 1917 and in the 1920s all new issues overseas were in New York in U.S. dollars (in contrast to the prewar overseas issues in London in sterling). There were new 
issues in the domestic markets also, but they were limited to rolling over the Victory Loans.

Canada's currency mismatch on the eve of the Depression might have left her exceptionally vulnerable. Interest on the public debt was about one third of government expenditures (high even relative to post World war II standards). In the early thirties the Canadian government considered a depreciation but rejected such a policy not because it would imply an increase in the real value of external interest payments, but rather because such policies could lead to "a flight from the Canadian dollar through fear of deflation" and the belief that depreciation "would be ruinous alike to the credit and to the future development of this country" (cited in Bordo and Redish, 1990; 372).

The government's protection lay in the extended maturities of the outstanding foreign debt, which meant that the immediate liabilities of the government were not large. In March 1932, the government had \$1.34 billion in gold bonds outstanding, but only \$34 million were due in the coming 12 months so that the combined interest and principal due in gold was only $\$ 93$ million. ${ }^{13}$ A significant, but not fatal, sum in relation to exports, implying that depreciation would not impose a critical burden on the public purse.

Canada dramatically reduced its currency mismatch/gold liabilities by the Conversion Loan of (March) 1931. By that loan, the government took advantage of the low interest rates of 1931 to roll over much of the outstanding Victory loans into 20 year bonds. In the process the gold clause was removed. While this may have been a shrewd

\footnotetext{
13 The $\$ 1.34$ billion includes $\$ 790$ million in gold bonds in Canada, and the $\$ 93$ million includes \$36.67 million in interest due on those bonds. It is extremely unlikely that the government would have paid Canadians in gold. On occasions when gold had been demanded the government's response that since gold could not be exported it was only worth its face value, and that a suit for damages would be rejected. The Ontario government asked Ottawa for help in halting the practice of Canadians sending their 'gold'
} 
prelude to the depreciation of October 1931, it seems unlikely: The government was not honoring the gold clause for domestic bond holders - the majority - anyway. ${ }^{14}$

Throughout the period, the link between denomination of the debt and the place of issue remained close. There were no foreign issues of Canadian dollar denominated debt. Yet there was some intermediation similar to the case of the U.S. in the nineteenth century. In 1948, a DBS survey of the Balance of Payments stated that an "appreciable total" of Canadian dollar denominated securities were held outside Canada, "even before the recent war". These would have been bonds issued in Canada, and most likely bought by U.S. insurance companies. Unfortunately the context does not help define "appreciable"!

Australia too developed its own debt market during World War I, and continued to issue domestically in the interwar period. One advantage of issuing at home in the late 1920s and early 1930s was the lower face value interest rate on debt. The average face value rate in London and New York was about 4.86 while debt issued locally had an average face value interest rate of 3.8 percent (Yearbook of Australia, 1934; 405). Despite moving towards domestic sources, officials in Australia noted the benefit in lower interest payments when sterling was devalued in September 1931 (Yearbook of Australia, 1939), and argued in August 1931 that further local depreciation would have aggravated the government deficit due to the increase in the interest charges on external debt. External debt therefore was not in domestic currency. On the other hand, both the international and the domestic debt continued to be relatively long term. Table 6 shows

coupons to U.S. banks to receive interest there in the gold they would not be paid in Canada! See Bordo and Redish, 1990. 
that the average maturities ranged from about 10 years for the internally issued debt, to roughly 20 years for the externally issued debt.

New Zealand cut the link to gold in 1929, much earlier than most countries during the Great Depression. The dependency on exports of primary goods was associated with a sudden onset of the crisis in this year. Nearly half of New Zealand's debt was issued in London at this time and nearly all of this was held abroad and payable in sterling in London. $^{15}$

Some tabulations available also suggest that the average maturity until payment on New Zealand debt was slightly longer on debt issued in London (13.2 years) than on debt issued at home (12.5 years). The average face value of interest charges on debt in 1939 was again higher in London at 4.25 percent versus 3.44 on internal debt (New Zealand Official Yearbook, 1939-40) .

The growth rate of the South African public debt during World War I was considerably less than that of the other British Dominions discussed here and, most likely as a result of that, the shift to domestic bond issues relative to foreign issues was least marked in that country. Nevertheless, the share of sterling debt in South Africa fell from 90 percent in 1910 to 70 percent in 1920 and to 60 percent by 1930 . The experience of South Africa during the depression was also somewhat anomalous, because of the increasing real value of the gold resource and hence the ability to service external debt.

\footnotetext{
${ }^{14}$ In addition the records show virtually no debate over the gold clause; the deputy minister of finance asked once for a list of loans with exact wording "in regard to the question of payment in gold" but the list is not in the records and there is no further mention of it.

${ }^{15}$ By 1939 one figure suggests that for $£ 17$ million of debt outstanding issued in London (a part of the external debt) about $£ 1.1$ million were held by New Zealand institutions. Another reference in the New Zealand Yearbook of 1939 suggests that of $£ 5.2$ million of interest payments on debt issued in London about 2 percent was payable in New Zealand to domestic holders of Sterling denominated debt.
} 


\section{World War II and Bretton Woods}

Throughout this period, the correspondence between currency of issue and place of issue remained strong, and as in World War I, government debt grew dramatically, and was funded domestically, leading to a further erosion in the share of the debt funded overseas.

The Canadian government continued to issue domestic debt in Canadian dollars, while New York issues were payable (at least optionally) in U.S. dollars, and London issues were payable in sterling. But even more than before the war, there is evidence of Americans buying Canadian dollar denominated debt issued in Canada. By the end of 1946 it is estimated that about $\$ 600$ million of such debt was held in the U.S., significantly more than the $\$ 178$ million of U.S.\$ denominated Canadian debt outstanding, but a negligible proportion of the $\$ 16.6$ billion in $\mathrm{C} \$$ denominated Canadian debt outstanding.

Data on purchases and holding of Canadian debt by non-residents starts to become available after World War II, and we can trace the development of foreign holdings of Canadian debt by currency with some precision. The Canadian government did not issue very much debt during the Bretton Woods period, but Figure 4 shows that of the amount purchased by non-residents an average of 17 percent was denominated in Canadian dollars. There are no records of foreign issues of Canadian dollar denominated bonds, so that this represents bonds bought - most probably by Americans - in Canada. Again insurance companies were highly represented amongst buyers.

To fund chronic public imbalances, Australia issued debt in many different foreign markets between 1950 and 1972, and, as in Canada, the currency of denomination 
typically coincided with the place of issue. Debt was issued in sterling, U.S. dollars, and to a lesser degree Swiss Francs, Canadian Dollars, Deutsche Marks, Dutch Guilders and Japanese Yen. The government attempted to use the depth of foreign markets in order to insure that adequate funding was available. It does not appear that any significant amount of debt sold overseas was denominated in Australian dollars during this period. Evidence on average maturity lengths for domestic currency denominated domestically issued debt shows that the average maturity, which had fallen from 8.99 years in 1939 to 6.25 years in 1955 , rose secularly to 10.3 years in 1972 .

In New Zealand, the amount of government debt increased 7-fold during World War II, but the level of sterling/London indebtedness did not change, explaining the dramatic decline in the amount of outstanding debt issued overseas. The story in South Africa is similar, with a 10-fold increase in domestically issued, domestic currency debt, and a contraction in the sterling/London debt. ${ }^{16}$

\footnotetext{
${ }^{16}$ Further work should investigate not only issues but residency of creditors.
} 


\section{Post Bretton Woods}

This period has seen radical innovations in the debt markets, so that by the end of the period, the use of derivatives has detached the currency of a liability from both its place of issue and its initial currency of issue. A key step in this evolution was the development of the Eurobond market. This market first developed in 1963 following the introduction of the U.S. interest equalization tax - designed to stem capital (and hence gold) outflows - which raised the cost of foreign borrowing in the U.S. Similar markets later developed for currencies other than the dollar. ${ }^{17}$

In November 1974, the Bank of Canada amended the perennial title of Table 29 "Net new securities issues payable in foreign currency" by adding in parentheses “includes Canadian dollar issues placed in overseas markets". This seems like an appropriate signal of Canada's baptism: Figure 4 shows that beginning in 1974 there was a gradual increase in the amount of Canadian dollar denominated new issues purchased by non-residents. In the 1980s, non-resident purchases of new issues both in foreign currency other than the U.S. dollar, and in Canadian dollars rose sharply. Portfolios saw the same transformation as the new issue market.

"In 1980, only 18 percent of Canadian bonds held by non-residents were payable in Canadian dollars, while 71 percent were payable in U.S. dollars. By 1993, Canadian dollar bonds represented 43 percent of Canadian bonds held by non-residents, while the share of U.S. dollar bonds had fallen to 44 percent." Bank of Canada $(1994 ; 47) .{ }^{18}$

\footnotetext{
${ }^{17}$ Eurobonds are generally bearer bonds, are tax free, are underwritten by an international syndicate of banks and are sold mainly in countries other than that of the currency of denomination (Davis 1992).

${ }^{18}$ Bond issues, with the exception of Federal government issues, were often placed in the Euro-bond market. (Bank of Canada, 1994; 43).
} 
A similar picture is painted by estimates from the Economic Council of Canada (1990; 72). They find that the amount of Canadian bonds denominated in Canadian currency placed outside Canada and the United States rose from \$5 million in the period 1963-70 (.5 percent of all Canadian issues placed outside Canada and the United States), to $\$ 4$ billion (30 percent) in the period $1971-80$, and to $\$ 16$ billion ( 25 percent) from 1981-87.

In Australia the 1980s was a period of debt consolidation and heightened concern with the debt. Australia's total foreign debt to GDP ratio was over 40 percent in the mid1980s (Argy, 1995). During these years, the debt management strategy changed radically in an attempt to reduce the real burden. Exchange rates were allowed to float, so volatility and average servicing costs could not be taken for granted. In addition the Australian market became deep enough to supply more funds for government borrowing needs. The government has not issued any debt abroad since 1987. At that point in time, foreign currency denominated debt equaled about 30 percent of the total outstanding debt. By the early 1990s the gross debt to GDP ratio had declined to 16 percent and the amount of foreign denominated debt outstanding was falling rapidly. By 1997 foreign currency denominated debt was a mere one percent of total debt. ${ }^{19}$

New Zealand's gross public debt to GDP ratio has fallen since the early 1990s from almost 50 percent to 32 percent. New Zealand is still exposed to foreign currency liabilities. The ratio of external debt to internal debt is about 25 percent as of 2001 . This is a large decline from the beginning of the 1990s when the proportions were almost

\footnotetext{
${ }^{19}$ However, the government has used swaps and other instruments to increase its exposure to the U.S. dollar as part of its diversification efforts (Johnson, 1997). It appears that some amount of U.S. dollar exposure provides a hedge for other debt outstanding.
} 
equal. In 1993 roughly half of the external debt was issued in U.S. dollars, while the rest was issued in other key currencies.

On the other hand there is also some evidence that non-residents are willing to hold "internal debt" or bonds denominated in New Zealand dollars. Figure 7 shows that foreign holdings of New Zealand dollar denominated debt peaked around 1997 at 16 percent of the total internal debt. This is most likely a lower bound on holding however as not all foreign bondholders could be identified accurately in the registers.

In South Africa, the public external debt stayed low as a percentage of total public debt after 1970 although there is a slight rise in recent years (Figure 2). Corroborating this secular rise in domestic credibility or financial capacity we see in Figure 8 that maturity lengths on domestically issued debt lengthened. This may in fact be a continuation of trends that emerged in the 1930s. It appears that credibility has its roots in the 1930s (as we have seen the maturity length increased slightly from 10.7 to 12.6 years

for domestic debt between 1928 and 1937). ${ }^{20}$ Figure 9 shows that a significant percentage of South Africa's total gross debt payable to non-residents (i.e., public and private) has been denominated in Rand since at least 1994. Since the 1960s, South Africa has issued external debt in a number of different currencies.

\section{Summary}

The evolution of government borrowing in the British Dominions is easy to summarize. Prior to 1913, borrowing was almost entirely long term bonds issued in pounds sterling in the London market. During the war, domestic savings were tapped by the issue of domestic debt which was denominated in domestic currency though often this 
carried a gold clause. The interwar period saw much of the domestic war debt rolled over, and at least in Canada, without a gold clause. Canada and Australia borrowed in the New York market, in U.S. dollars. World War II again led to expanded domestic debt as a percentage of the total, and during the postwar/Bretton Woods period there was little access to foreign capital markets. The breakdown of Bretton Woods and growth in government borrowing in the 1970s led to an expansion of external debt, and all the Dominions began issuing a significant amount of domestic currency debt overseas.

\section{Some Explanations for the Patterns Observed}

Below we review the salient patterns observed in our case studies of debt history of the Anglo countries. We then pose some explanations for the common patterns observed for the five countries and for some special features of the United States.

\section{The Patterns in Evolution away from Original Sin}

Across all five of our countries we see little evidence in the historical record of Original Sin in the sense of an inability to borrow at long-term maturities whether domestically or abroad. There are a few episodes when maturities shortened, especially during the Great Depression, but these rarely affected the average maturity length.

For Original Sin in the sense of the inability to issue domestic currency denominated debt abroad, none of the countries were completely free of it until the third decade of the twentieth century. The U.S. was the leader, it weaned itself from foreign

\footnotetext{
${ }^{20}$ This excludes a large amount of debt without a definite redemption date.
} 
currency (guilder) sovereign debt very early in the nineteenth century and dollar debt was listed and issued on foreign markets with implicit or later explicit specie or gold clauses until the Great Depression. States and corporate debt followed a similar pattern of evolution from Sterling to dollar debt with gold clauses later in the nineteenth century.

The Dominions borrowed externally in sterling exclusively until World War I, but developed domestic debt markets after this. After the war there was a decline in reliance on external debt. It was only after the breakdown of the Bretton Woods system and the advent of derivatives that these countries began issuing external debt in their own currencies. In the secondary markets it appears that local currency debt (sans gold clauses) has been held abroad since the 1950s in Canada and although our evidence is somewhat incomplete it appears that similar patterns emerged in the other countries by the 1970 s.

\section{$\underline{\text { Explanations }}$}

We explore the factors that contributed to the changing patterns that we have discussed. While the data are not structured in a way that facilitates statistical techniques we have sufficient information to make some informed conjectures on some of the leading hypotheses posed in this volume as well as on other determinants. We initially consider four factors that might explain the common pattern of evolution away from Original Sin across the five countries: sound and credible fiscal institutions; credible monetary regimes; financial development; major shocks. We then discuss two factors that made the U.S. experience different from that of the Dominions: size and the effect on 
how much of a "vehicle" the currency was; and, the differing extent of dependence and independence from Europe.

\section{Sound and Credible Fiscal Institutions}

Corsetti and Mackowick (this volume) suggest that weak public finances could lead governments to address imbalances with an inflation tax. Fearing this, agents avoid long-term, non-institutional domestic currency debt and hold only foreign currency debt. This was not the case in our five countries all of which had developed relatively sound fiscal institutions by the nineteenth century compared to today's emergers.

In 1790 Hamilton the Secretary of the Treasury from 1789 to 1795 put together one of the most successful financial programs in history. The package included four elements: funding the national debt, creation of a sinking fund, securing sufficient tax revenue, and creation of a national bank, the First Bank of the United States (Perkins 1994 Bordo and Vegh 2002). His program was based on the idea that domestic bond prices were a measure of the creditworthiness of a nation, and he attempted to increase that price through timely domestic interest payments, consolidation of all federal and state debt and "small-scale redemptions". This improved the chances of garnering further domestic confidence and attracting more foreign loans at favorable terms. In addition a sinking fund was also established to "manipulate" the price of bonds in the open market and to enhance credibility. Finally, the whole package was secured by instituting a national tariff of 10 percent on import values as well as excise taxes to provide sufficient tax revenues to continuously service the debt. These policies succeeded in raising domestic bond prices, enlarging the domestic bond market and ultimately reinforcing the credibility of the foundling republic. 
The Funding Act of 1790 and Hamilton's ability put American credit on a trajectory to gain a strong international reputation. This Act, along with the Napoleonic wars, paved the way for a European interest in domestically issued American securities with implicit specie clauses. The wars made investments in the fledgling country look relatively more secure, and the Funding Act was a provision "to fulfill the engagements of the U.S. in respect to foreign debt."

Hamilton's plan was based on British precedent - the creation of a long-term bond market and permanent servicing with indirect taxes - set in the early eighteenth century. Similar institutions were adopted by Canada (Bordo and Redish 2001) and the other British Dominions in the nineteenth century.

The principal exception to the story of fiscal probity was the U.S. States in the 1840s. Their defaults shut them out of foreign markets for an extended period (Wilkins 1989). These events did not help the progression to be free of Original Sin.

The Federal government in the U.S. developed a sound fiscal base with Alexander Hamilton's stabilization package. Overall, this plan allowed for a very limited graduation from Original Sin as we have argued above. Subsequent reliance on explicit gold clauses suggests however that it takes more than sound finances to completely break free.

\section{Credible Monetary Regimes}

Jeanne (this volume) suggests that agents favor foreign currency denominated debt when domestic monetary policy is not credible. Bad monetary policy increases the ex ante interest rate on domestic currency denominated issues. Likewise it might be argued that if policy were credible then these costs should disappear releasing countries from Original Sin. 
The history of all five countries suggests that lack of credibility in the monetary regime was not a necessary condition for Original Sin and credible monetary regimes were not sufficient to be totally free of it. For the most part all of these countries had credible regimes over the long-run. All the countries were part of the specie standard that prevailed until World War I. All credibly followed the rule of the maintenance of convertibility as paramount. The rule followed was contingent in the sense that credibility could be temporarily suspended in the event of a wartime emergency which indeed was the case during and after the U.S. civil war and for the Dominions, during World War I (Bordo and Kydland 1995).

The U.S. case was most interesting because the specie standard followed de jure until 1900 was bimetallic, leaving open the possibility of silver risk and hence the need for gold clauses. The U.S. remained on the gold standard until 1933 when Roosevelt abrogated the gold clauses. After World War II, the dollar (officially convertible into gold) became the key currency of the world and U.S. dollar debt was widely held abroad. This has continued with the demise of Bretton Woods and the advent of a fiat money regime. Although the U.S. followed unorthodox monetary policy in the Great Depression and in the Great Inflation of the 1970s neither the dollar nor dollar debt was ever shunned.

Canada was on the gold standard from its origins as a British colony, with the Canadian dollar fully convertible into gold until 1914. Australia, New Zealand and South Africa were fully 'sterilingized' prior to the turn of the twentieth century and then turned to gold standard adherence with domestic currencies. These countries credibly adhered to the gold standard and followed the contingent rule during World War I. In the Bretton Woods years, all the Dominions except Canada followed the adjustable peg. Canada 
floated from 1950 to 1962 but followed a more stable monetary policy than the U.S., which suggests it may have continued to follow the contingent rule (Bordo 2001). In the immediate post Bretton Woods, all the Dominions had similar inflationary experiences to the other advanced countries and since the mid 1990s have learned to follow a fiat nominal anchor with low inflation.

\section{Financial Development}

Authors such as Chamon (2002) have emphasized that the inability to write complex agreements that maintain the value of domestic currency denominated debt in the case of depreciation diminishes the size of the domestic currency debt market. Also Caballero and Krishnamurthy (2002) argue that financial under-development can lead to excessive hard-currency debt.

All five of our countries had significant financial development by the end of the nineteenth century. All of the countries had extensive banking systems and high ratios of M2 to GDP (Bordo and Flandreau 2003). The Dominions had nationwide branch banking which encouraged financial stability. In the Dominions, the banks were the dominant financial intermediary, supplemented by insurance companies and investment dealers (Davis and Gallman 2001).

The U.S. had unit banks prone to runs and panics. In the U.S. in part because of the restrictions on branching and inter state banking which hobbled the size of bank assets, other financial markets and institutions such as commercial paper, stock markets and investment banks evolved to fill the gap. 
None of the countries had central banks before 1910. With the establishment of the Federal Reserve in 1914 and central banks in the Dominions by the end of the 1930s this absence was corrected. In the U.S., the lack of a lender of last resort was only partially made up by alternative private arrangements (clearing house loan certificates) and Treasury actions. Banking crises were frequent. In the Dominions, large commercial banks served as the governments' fiscal agents and with the Department of Finance (e.g. in Canada) served as Lenders of Last Resort. Banking crises were a rare event, with the principal exception of Australia in 1893.

Financial underdevelopment was unlikely to be a reason for Original Sin in these countries. It took a major financial innovation -- the development of derivatives in the 1970s for the Dominions to issue external debt in their own currencies. It took terrible economic woes to end hard currency debt in the U.S.

\section{Shocks}

The record for all five of our countries demonstrates that the major changes in patterns of evolution away from Original Sin occurred after wars and other significant shocks. The evidence suggests that these disturbances forced the creation of markets for the local currency debt. For example, World War I made it very costly (or impossible) for the Dominions to borrow in the London market. This may have made it more rational for economies to bear the high start-up costs of creating a domestic debt market. After those costs were borne, the domestic markets continued to flourish even after normal conditions prevailed in the traditional markets. These facts highlight how path dependence can help explain how nations break free from Original Sin. 
In the U.S. case, foreign holdings of dollar denominated debt (with implicit versus explicit gold clauses) rose rapidly after the Revolution and Hamilton's revamping of the fiscal system between 1790 and 1803. The Great Depression ended the gold standard and the gold clauses. The same was true to an extent in Canada.

Similarly, in the Dominions, World War I was the key event that led to the rise of domestic currency internal debt relative to external sterling debt and for Canada initially, the substitution of US dollar external debt in place of sterling. It is after World War II that first we see evidence of non-residents holding internally issued Canadian dollar debt. Finally the breakdown of the Bretton Woods System with the advent of nominal floating and the end of capital controls set the stage for the development of the derivatives that led to the creation of international bonds in the Dominion currencies.

\section{U.S. Exceptionalism and the Role of History}

We posit that the U.S. was different from the other Anglo countries in its ability to abstain from loans denominated in foreign currencies and to have its securities listed in dollars in foreign markets. Two factors are responsible.

\section{Key Currencies and Size}

The U.S. was different from the others because of its economic size and political importance. Moreover, although it was less dependent on international trade than the others, its volume of trade and the network of international transactions was also an order of magnitude greater. Such factors have long been identified as the hallmarks of vehicle currencies which are used to invoice trade and financial contracts. Indeed Wilkins (1989) 
reports that in the nineteenth century domestically issued U.S. debt often ended up abroad

because agents viewed the assets as useful in international transactions.

From the very beginning the U.S. explicitly tried to avoid sovereign debt in foreign currencies, as evident in the following quote from Alexander Hamilton

" The Payment of interest and installments of principal of our foreign debt in the countries where it was contracted is found by experience to be attended with difficulty, embarrassment, some loss, and a degree of casualty which occasionally puts in jeopardy the national credit. Loans for reimbursement must be made beforehand, as the market suits, and necessarily involve double interest for a greater or less time. The procuring of bills to be remitted for payment of interest cannot be depended upon in coincidence with the periods of payment, which, co-operating with distance, renders inconvenient anticipations necessary. ... If, therefore, the place of these could, with consent of the creditors upon an equitable indemnification to them for the transfer, be changed to the United States, the operation would be, in various lights, beneficial ...... [proposal to convert all foreign debt to domestic debt]

It could not be necessary to observe, except for the sake of dispelling jealousy or apprehension on the part of the creditors, that while the plan is experiment, and afterward, with regard to all who do not embrace it, [itals. in original] everything is to proceed as heretofore, and as the contracts respecting the debt require." $\left(10^{\text {th }}\right.$ census v.7. p.334).

It is unlikely a small country could have created a debt market from scratch as Hamilton did. The Funding Plan converted and consolidated nearly all outstanding debt to domestic debt. Moreover, as the country developed in the nineteenth century and financial markets expanded and deepened, the states and corporations were able to fund much of their requirements in the domestic markets obviating the need for foreign debt regardless of the currency of denomination.

The U.S. dollar did not fully emerge as a key currency until after World War I but by the end of the nineteenth century it was on a par with European currencies other than those of the core countries (Lindert 1969). Finally, the thick market externalities associated with the medium of exchange may have factored into the denomination of assets as is the case with the medium of exchange. 


\section{The British Empire}

All of the areas we analyze were once British colonies, and for the countries besides the U.S. nearly all had special relationships with the British until very recently. Colonial status and special relationships entailed sundry institutional connections that might have made it simply more convenient to issue debt in sterling. Three of these countries (Australia, New Zealand and South Africa) used sterling until the twentieth century and it was legal tender in Canada. Even if there was a financial crisis, colonial status could avoid the negative repercussions of balance sheet effects. Debtors and creditors could reschedule debt more easily. If worst came to worst, government intervention could make debtors repay by rights guaranteed in the colonial stock acts; denomination in sterling facilitated accounting and eliminated day to day risk for British creditors.

Borrowing in London for the Dominions also had a significant financial advantage over domestic borrowing as borrowing costs were lower there. This is precisely the opposite of Hamilton's observation about the expenses of issuing debt abroad that we mentioned above. Still we realize that this only explains the denomination of the debt instruments insofar as place of issue equaled the currency of denomination in the nineteenth century.

Commonwealth ties may have been significant in other ways. Under the Colonial Stock Acts, colonial public debt was often admissible to be held by trusts in the U.K. (see Ferguson (2002)). Also, the proceeds of debt issues were often spent on capital goods to be imported from Britain, and loans were (indirectly) repaid with exports sold in Britain, the costs of currency mismatch were reduced.

Take as an example Australia which had accumulated one of the highest debt per capita ratios in the world at over $£ 100$ by the interwar period. During the 1930 s policy- 
making was contentious, and exchange rate policy was on the minds of policy makers because of the possibility of increased interest payments if Australia were to stop shadowing the pound. The liberal Premier of New South Wales proposed suspending payments on external debt. Nevertheless a more orthodox conversion process carried the day. After 1932, Australia engaged in a number of loan conversions in London, rewriting the contracts for over one quarter of all external debt. Exchange savings were large (Official Yearbook of the Commonwealth of Australia, 1933-34). These conversions stipulated payment in pounds sterling while external debt issued in the 1920s was originally to be paid in a fixed amount of gold. Conversions between 1932 and 1934 list savings in terms of exchange of 25 percent, corresponding to the depreciation of sterling from pre-Depression parity.

In New Zealand during the interwar period because of the increase in debt charges, the country was forced to devise various means of easing the burden. The newly created central bank, the Reserve Bank of New Zealand, founded in 1933, enacted various plans including the total conversion of nearly all of the domestic debt outstanding. In 1934 a conversion of externally issued debt was undertaken as well. Most importantly, under the Hoover plan for debt forgiveness, Great Britain refrained from demanding repayment of $£ 24$ million in war debts after 1931 .

In sum, our survey suggests that few of the factors cited in the recent literature on Original Sin in today's emerging markets were pivotal for the experience of the Anglo countries studied here. These countries had sound fiscal institutions, adhered to credible monetary regimes and were financially developed over a century ago. The key factor in their progression from Original Sin in the sense of issuing external debt in terms of their 
own currencies or generating local currency debt that was held by non-residents, was a response to shocks - - wars, the Depression and the collapse of Bretton Woods.

The U.S. evolved at a much more rapid pace than the others in part because of its size. This allowed it to generate a market for domestic debt and made it less costly to hold the debt despite the lack of an explicit gold clause. Finally we attribute some of the delay in the Dominions to special features of the British Empire making foreign currency debt less costly for the borrowers.

\section{Conclusion}

In conclusion we raise and answer some questions suggested by our study of the debt history of the five former British colonies. First, was there Original Sin in the five countries? The answer is no in the sense that all countries studied issued long-term domestic debt from the earliest years of their experience. The answer is yes in the sense that until well into the twentieth century, their external debt was denominated in foreign currencies (the Dominions) or had gold clauses (the U.S.). For the U.S. the key feature is the ambiguity in the gold clauses suggesting a somewhat more advanced trajectory.

Second, how did they get free from Original Sin? The answer seems to be that it took big external shocks to eliminate the vestiges of Original Sin. For the U.S. the Revolutionary war set the stage for Hamilton's fiscal miracle and the Great Depression ended gold clauses. For the Dominions it was World War I, which ended dependence on sterling debt and the demise of Bretton Woods that provided the derivatives that made it possible to issue foreign bonds in currencies with thin markets.

Third, does Original Sin come and go? Our long run view suggests that this is a possibility but any change is strictly marginal. Gold clauses became more explicit in the 
late nineteenth century U.S. following uncertainty about the currency. Maturities on new issues declined during the Great Depression. In the Dominions similar evidence for changes in holdings and maturities is evident. Still, the evidence indicates only large shocks not associated with these factors can make large changes.

Finally, did the presence of Original Sin in the Anglo countries matter back then as much as it does for today's emergers. The answer we posit is no. The five countries had sounder fiscal and monetary institutions than today's emergers. Their financial policies were more credible (with the exception of the interwar period) and they were less exposed to the balance sheet risks of maturity mismatches because their debt was mostly long-term, and to currency mismatches because the amounts involved were relatively small.

This different experience is reflected in the incidence and severity of financial crises in the five countries over the past century compared to the emergers today. Of the four Dominions surveyed, the only country to have a serious crisis on the scale of the recent Asian crises was Australia which had a banking crisis in 1893, (Bordo and Eichengreen 1999, Delargy and Goodhart 1999) ${ }^{21}$. The U.S. of course had several serious banking crises between 1880-1914 and one twin crisis (1893). It also had the banking panics of the 1930s. The Dominions also had a number of currency crises in both the interwar and Bretton Woods periods, but all of these reflected overvaluation and the inherent flaws of the Gold Exchange Standard and the adjustable peg regimes. None of these crises however were associated with the balance sheet effects associated with recent

\footnotetext{
${ }^{21}$ New Zealand had a milder crisis in 1893 (Butlin 1960). South Africa also had a banking crisis 1889-1890 (Schuman 1938)
} 
emerging market crises that induced debt crises and defaults. This record suggests that while Original Sin may have been present in our five countries it didn't really matter. 


\section{$\underline{\text { References }}$}

Argy, Victor (1995) "Monetary and Exchange Rate Policies 1973-1991: The

Australian and New Zealand Experience”. in Edwards, Sebastian ed. Capital Controls,

Exchange Rates and Monetary Policy in the World Economy. Cambridge University

Press: Cambridge.

Bank of Canada (1994) "Canada's international net indebtedness" Bank of Canada

Review (Summer).

Michael D. Bordo and Marc Flandreau (2003), “ Core, Periphery, Exchange Rate Regimes and Globalization.” In Michael D. Bordo, Alan Taylor and Geoffrey Williamson (eds.) Globalization in Historical Perspective. Chicago, University of Chicago Press (forthcoming)

Michael D. Bordo and Carlos A. Vegh (2002), "What if Alexander Hamilton Had Been Argentinean? A Comparison of Argentina and the United States." Journal of Monetary Economics. April.

Michael D. Bordo (2001) “ Alternating Exchange Rate Regimes: The Canadian Experience 1820-2000." Revisiting the Case for Flexible Exchange Rates, Bank of Canada, Ottawa.

Michael D. Bordo and Angela Redish (2001) “ The Legacy of French and English Monetary Institutions for Canada." in Michael D. Bordo and Roberto Cortes-Conde Transferring Wealth and Power from the Old World to the New World: Monetary and Fiscal Institutions in the $17^{\text {th }}$ through the Nineteenth Century: New York, Cambridge University Press. 
Michael D. Bordo and Barry Eichengreen (1999) “ Is Our Current International Economic Environment Unusually Crisis Prone?" in Capital Flows and the International

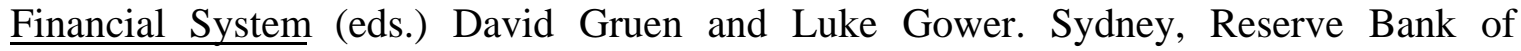
Australia.

Michael D. Bordo and Finn E. Kydland (1995) “ The Gold Standard as a Rule: An Essay in Explorations." Explorations in Economic History. October.

Michael D. Bordo and Angela Redish (1990), “Credible Commitment and Exchange Rate Stability: Canada's Interwar Experience." Canadian Journal of Economics, Vol. XXIII No.2 (May).

S.J. Butlin (1961) Australia and New Zealand Bank: The Bank of Australia and the Union Bank of Australia Limited, 1820 -1951. London Longmans.

Ricardo Caballero and Arvind Krishnamurthy (2001) “ Excessive Dollar Debt: Financial Development and Under Insurance." Northwestern University mimeo September.

Marcos Chamon and Ricardo Haussman (2002) "Why do Countries Borrow the Way they Borrow?" Original Sin Conference, Harvard University. July.

Giancalo Corsetti and Bartosz Mackowiak (2002) “ Nominal Debt and currency Crises" Original Sin Conference, Harvard University. July.

E.P. Davis (1992), “Euromarkets.” The New Palgrave Dictionary of Money and Finance. London Macmillan pp.783-785. 
Lance Davis and Robert Gallman (2000), Waves, Tides and Sandcastles: The Impact of Foreign Capital Flows on Evolving Financial Markets in the New World, 1865-1914. New World Cambridge: Cambridge University Press.

M.H. De Kock, (1922) Analysis of the Finance of the Union of South Africa VI. Capetown.

Delargy and Charles Goodhart (1999) “Financial Crises: Plus ca Change, plus c'est la meme chose. LSE Financial Market Group Special Paper No. 108.

Davis Rich Dewey, (1920) Financial History of the United States. Longmans, Green and Co., New York.

Economic Council of Canada (1990) Globalization and Canada's Financial Markets Canada: Minister of Supply and Services.

Barry Eichengreen and Ricardo Haussmann (1999), “Exchange Rates and Financial Fragility" Federal Reserve Bank of Kansas City. New Challenges for Monetary Policy pp. 329-368.

Elliot, Jonathan 1968 The Funding System of the United States \& of Great Britain New York: Augustus M. Kelley.

Niall Ferguson (2002), "Globalization and Gunboats: The Costs and Benefits of the British Empire Revisited”. Oxford University mimeo.

Marc Flandreau and Nathan Sussman (2002) “ Old Sins: Exchange Clauses and European Foreign Lending in the Nineteenth Century." Original Sin Conference, Harvard University, July. 
Frederick Field (1914) Capital Investment in Canada $3^{\text {rd }}$ Edn. Montreal: Monetary Times of Canada.

Milton Friedman and Anna J. Schwartz (1963). A Monetary History of the United States, 1867-1960. Princeton: Princeton University Press.

Holland, J.M. (1931) "Effect on South Africa of the Abandonment of Gold by Great Britain” Journal of the Institute of Bankers v. 29 pp. 354-66.

Hausmann, Ricardo and Hugo Panizza (2002) “The Mystery of Original Sin: The Case of the Missing Apple" mimeo. Kennedy School of Government.

Olivier Jeanne (2002) "Monetary Policy and Liability Dollarization.” Original Sin Conference. Harvard University. July.

Johnson, Andrew (1997) "Australian Government Foreign Debt Management" presentation at a conference entitled: World Bank Sovereign Foreign Debt Management Forum, Washington D.C. Available from the Australian Treasury at http://www.treasury.gov.au/documents/202/PDF/Article04.pdf.

Kroszner, Randall S.(2002) "Is it Better to Forgive than to Receive? Repudiation of the Gold-Indexation Clause in Long-Term Debt During the Great Depression” U. of Chicago mimeo.

Felipe Larain and Andres Velasco (2001) “Exchange Rate Policy in Emerging Market Economies: The Case for Floating" Essays in International Finance No.224. Princeton N.J. December.

Peter Lindert (1969) Key Currencies and Gold, 1900-1913. Princeton Studies in International Finance, No.24. Princeton: Princeton University press. 
Monthly Statement of the Public Debt Outstanding available at:

http://www.publicdebt.treas.gov/opd/opdhisms2.htm

Nash, Robert Lucas (various issues) Fenn's Compendium of the English and Foreign Funds, Debt, and Revenue of All Nations, Together with Statistics Relating to National $\underline{\text { Resources and Liabilities, Imports, Exports, Population, Area, Railway Guarantees, }}$ Municipal Finance and Indebtedness, Banks of All Nations and all Descriptions of Government, Provincial and Corporate Securities held and dealt in by Investors at Home and Abroad London.

New Zealand Official Yearbook (various issues) Wellington.

Official Year Book of the Commonwealth of Australia (various years), Melbourne.

Official Year-Book of the Union of South Africa and of Basutoland, the

Bechuanaland Protectorate, and Swaziland (various issues).

The Royal Institute of Affairs [RIA], The Problem of International Investment: A Report by a study group of members of the Royal Institute of Affairs Oxford University Press, 1937.

Edwin J. Perkins (1994), American Public Finance and Financial Services 1700-1815. Columbus Ohio: Ohio State University Press.

Ratchford, BU 1941 American State Debts Durham, North Carolina: Duke University Press.

Christian Gustav Waldemar Schuman (1938) Structural Changes and Business Cycles in South Africa 1806-1936. London, P.S. King. 
Robert G. Trevor and Stephen G. Donald (1980), "Exchange Rate Regimes and the Volatility of Financial Prices: The Australian Case." Economic Record. Supplement pp.58-66.

Myra Wilkins (1989) The History of Foreign Investment in the United States to 1914 Cambridge, Mass: Harvard University Press. 
Table 1: U.S. Dollar Debt of the Federal Government Held Abroad

\begin{tabular}{lcc}
\hline \hline Year & $\begin{array}{l}\text { Nominal Amount of Dollar } \\
\text { Denominated Debt Held Abroad } \\
\text { (millions of dollars) }\end{array}$ & As a percentage of total debt \\
\hline 1789 & 4 & $7 \%$ \\
June & 32.1 & $46 \%$ \\
1803 & 43.0 & $53 \%$ \\
$\begin{array}{l}\text { Dec. } \\
1803\end{array}$ & & \\
\hline \hline
\end{tabular}

Source: Wilkins (1989; 32, 36); Note: All dollar debt would carry an implicit gold-index clause.

Table 2: Nominal U.S. Federal Government Debt Outstanding in Foreign

Currencies

\begin{tabular}{lcc}
\hline \hline Year & $\begin{array}{l}\text { Nominal Amount of } \\
\text { Foreign Currency } \\
\text { Denominated Debt } \\
\text { (millions of dollars) }\end{array}$ & $\begin{array}{l}\text { As a percentage of total } \\
\text { debt outstanding }\end{array}$ \\
\hline 1789 & 11.7 & $21.6 \%$ \\
1796 & 11.9 & $14 \%$ \\
1804 & 5.7 & $6.5 \%$ \\
1810 & 0 & $0 \%$ \\
\hline \hline
\end{tabular}

Source: Wilkins $(1989 ; 35)$ 
Table 3: Amounts and Percentages of U.S. Federal Debt held Abroad, 1789-1884

\begin{tabular}{lcc}
\hline \hline Year & $\begin{array}{l}\text { Amount of Debt held } \\
\text { abroad (millions of } \\
\text { dollars) }\end{array}$ & $\begin{array}{l}\text { Percentage of total } \\
\text { public debt }\end{array}$ \\
\hline 1789 & 15.7 & $29 \%$ \\
1803 & 48.7 & $56 \%$ \\
1828 & 19.1 & $33 \%$ \\
1853 & 27.0 & $46 \%$ \\
1880 & 249 & $12 \%$ \\
1881 & 150 & $7.5 \%$ \\
1884 & 100 & $6.0 \%$ \\
\hline \hline
\end{tabular}

Source: Wilkins $(1989 ; 54,147)$.

Table 4 Various Issues of the United States Federal Government

\begin{tabular}{llll}
\hline \hline Issue & Year & Currency & Interest payable in/comments \\
4 1/2\% Funded & 1876 & Dollar & Payable in the coin standard of the United States \\
4\% Funded & 1877 & Dollar & Payable in the coin standard of the United States \\
Three percents & 1882 & Dollar & Payable in the coin standard of the United States \\
4 1/2\% loan of 1891 & 1891 & Dollar & Payable in the coin standard of the United States \\
4\% Loan & 1895 & Dollar & Payable in coin \\
3\% Loan & 1898 & Dollar & Payable in gold coin \\
2\% Thirty Year & 1900 & Dollar & Payable in gold coin \\
Bonds & & & \\
\hline \hline
\end{tabular}

Source: Stock Exchange Official Intelligence. 
Table 5 New Issues Of Selected U.S. Private Companies in London, 1887-1896

\begin{tabular}{|c|c|c|c|c|}
\hline Issue & Amount & Year & Currency & Interest Payable in/Comments \\
\hline Mobile and Birgmingham Railway Company 5\% Gold Bonds & $3,000,000.00$ & 1887 & Dollars & \\
\hline Great Northem Railway of Minnesota 4\% Extension Bonds & $3,000,000.00$ & 1890 & Sterling & \\
\hline Cleveland, Cincinnati, Chicago, St Loius Railway Mortgage 4,5\% Gold Bonds & $4,000,000.00$ & 1892 & Dollars & \\
\hline Illinois Central Railroad 4\% Gold Bonds & $4,000,000.00$ & 1893 & Dollars & \\
\hline Cleveland, Cincinnati, Chicago, St Loius Railway Mortgage 4\% Gold Bonds & $5,000,000.00$ & 1893 & Dollars & \\
\hline Baltimore and Ohio South Westem Railway Company & $250,000.00$ & 1893 & Dollars & \\
\hline Arizona Copper Company & $100,000.00$ & 1894 & Sterling & \\
\hline Chicago, Milwaukee and St. Paul Railway Company Gold Bonds & $2,000,000.00$ & 1894 & Dollars & \\
\hline Baltimore and Ohio South Railroad Company 4,5\% Gold Bonds & $8,164,000.00$ & 1894 & Dollars & \\
\hline St. Louis Merchants Bridge terminal Railway 5\% Gold Bonds & $3,165,500.00$ & 1894 & Dollars & \\
\hline Twin City Rapid Transit Company Shares & $1,500,000.00$ & 1894 & Dollars & \\
\hline Minneapolis Westem First Mortgage Bonds & $500,000.00$ & 1895 & Dollars & \\
\hline Terminal Railroad association of St Louis 5\% Gold Bonds & $4,500,000.00$ & 1895 & Dollars & Interest Payable in Gold Coin of the US \\
\hline Cleveland and Marietta Railway Company 4,5\% Gold Bonds & $1,250,000.00$ & 1895 & Dollars & Interest Payable in Gold Coin of The US \\
\hline Alleghany Valley Railway Company $4 \%$ Gold Bonds & $5,000,000.00$ & 1895 & Dollars & Interest Payable in Gold Coin of The US \\
\hline Pennsylvania Railroad Company 3,5\% Sterlin Bonds & $1,000,000.00$ & 1895 & Sterling & \\
\hline Alina Colony Corporation Shares & $116,067.00$ & 1896 & Sterling & \\
\hline Milwaukee Electric Railway and Light Company & $5,100,000.00$ & 1896 & Dollars & Interest n Coin of the Present Standard \\
\hline Elmira, Cortland and Norhtem Railroad Company & $1,250,000.00$ & 1896 & Dollars & Interest in Coin of the Present Standard \\
\hline Pacific Borax and Redwood's Chemical Works Ordinary Shares & $310,000.00$ & 1896 & Sterling & \\
\hline Pacific Borax and Redwood's Chemical Works Preference Shares & $200,000.00$ & 1896 & Sterling & \\
\hline Pacific Borax and Redwood's Chemical Works $5 \%$ Debentures & $100,000.00$ & 1896 & Sterling & \\
\hline
\end{tabular}

Source: Fenn on Funds and The Investor's Review

Table 6: Maturity Structure for States in Australia and the Commonwealth, 1932 and 1939.

\begin{tabular}{c|cccccc}
\hline & \multicolumn{3}{|c}{ Debt Payable by States in: } & \multicolumn{3}{c}{ Debt Payable by Commonwealth and States in: } \\
Year & London & New York & Australia & London & New York & Australia \\
\hline \hline & & & & & & \\
1932 & 19.02 & 22.23 & 10 & 19.5 & 22.6 & 11.8 \\
1939 & 19.38 & 16.28 & 9.19 & 11.45 & 10.03 & 8.99 \\
\hline
\end{tabular}

Notes: Debt is payable in the currency of market where it is payable. Amounts are converted to Australian pounds in the original source. 1934 includes $£ 79 \mathrm{~m}$ of debt payable in London on an annual basis. For column 6 the figures exclude $A £ 11 \mathrm{~m}$ of debt redeemable at an indefinite date or at the treasurer's discretion.

Sources: Commonwealth of Australia Yearbooks, 1933 and 1939. 
Figure 1. Percentage of All U.S. State Borrowing Falling Due between 3.1 and 5 years, 1919-1938

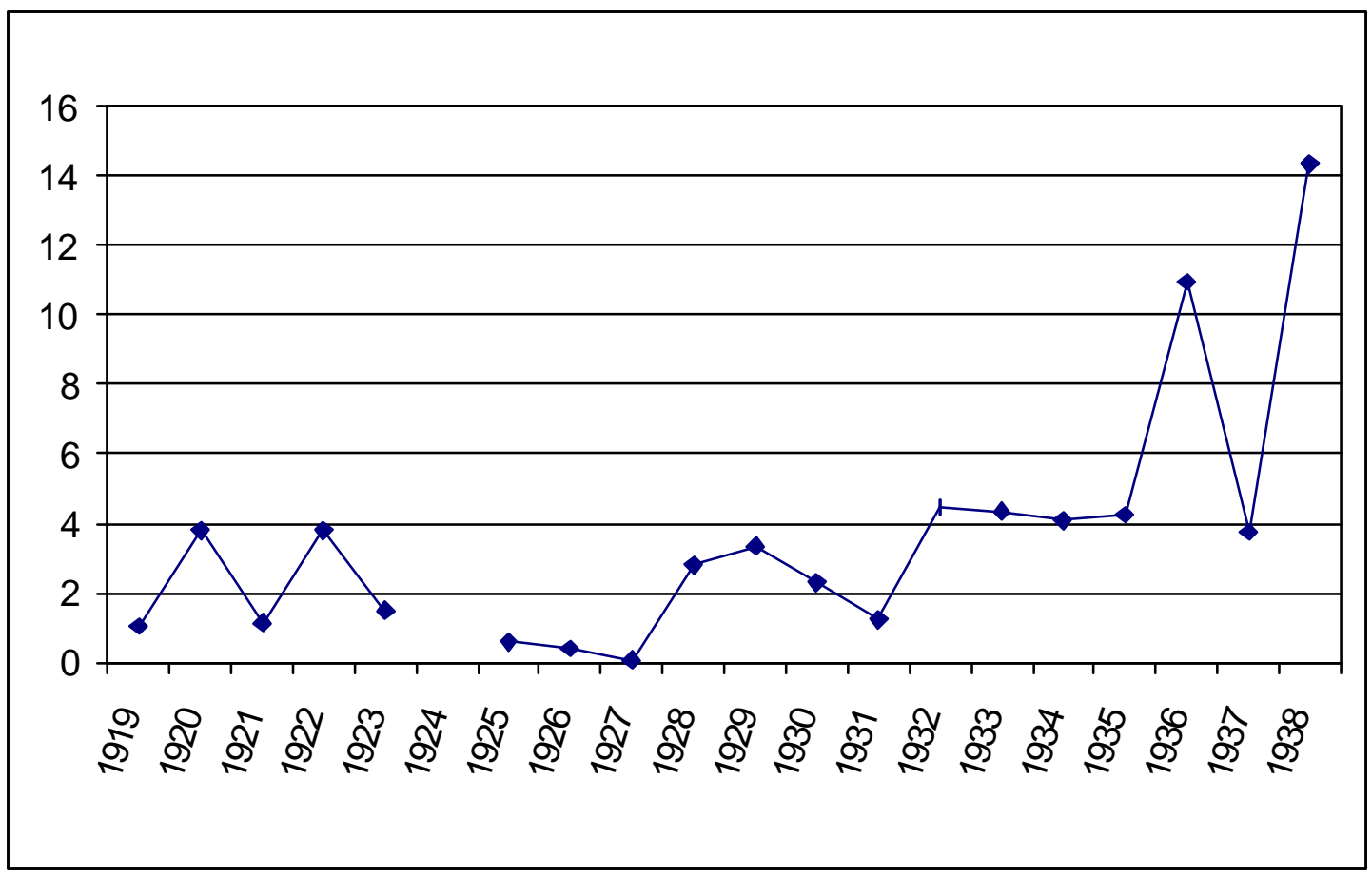

Source: Ratchford (1941) p. 274

Figure 2. Public Debt Issued Overseas in Foreign Currency as a Percentage of Total Outstanding Public Debt

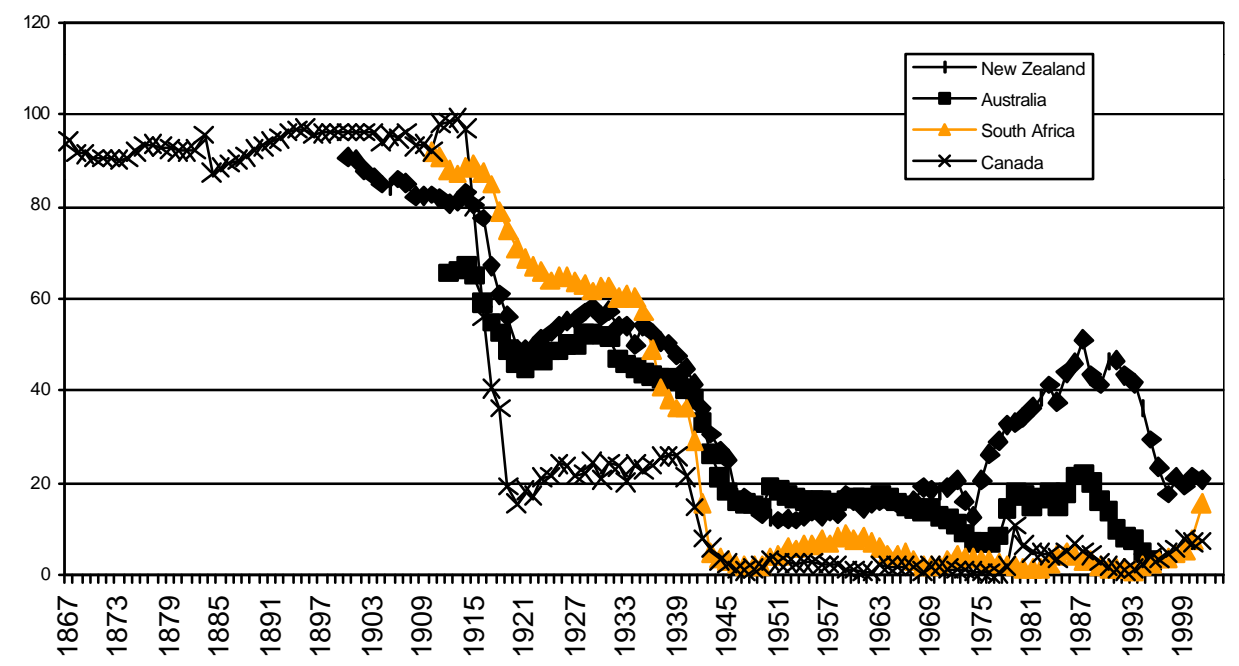


Figure 3: Australia and Great Britain, Exchange Rates 1870-2000.

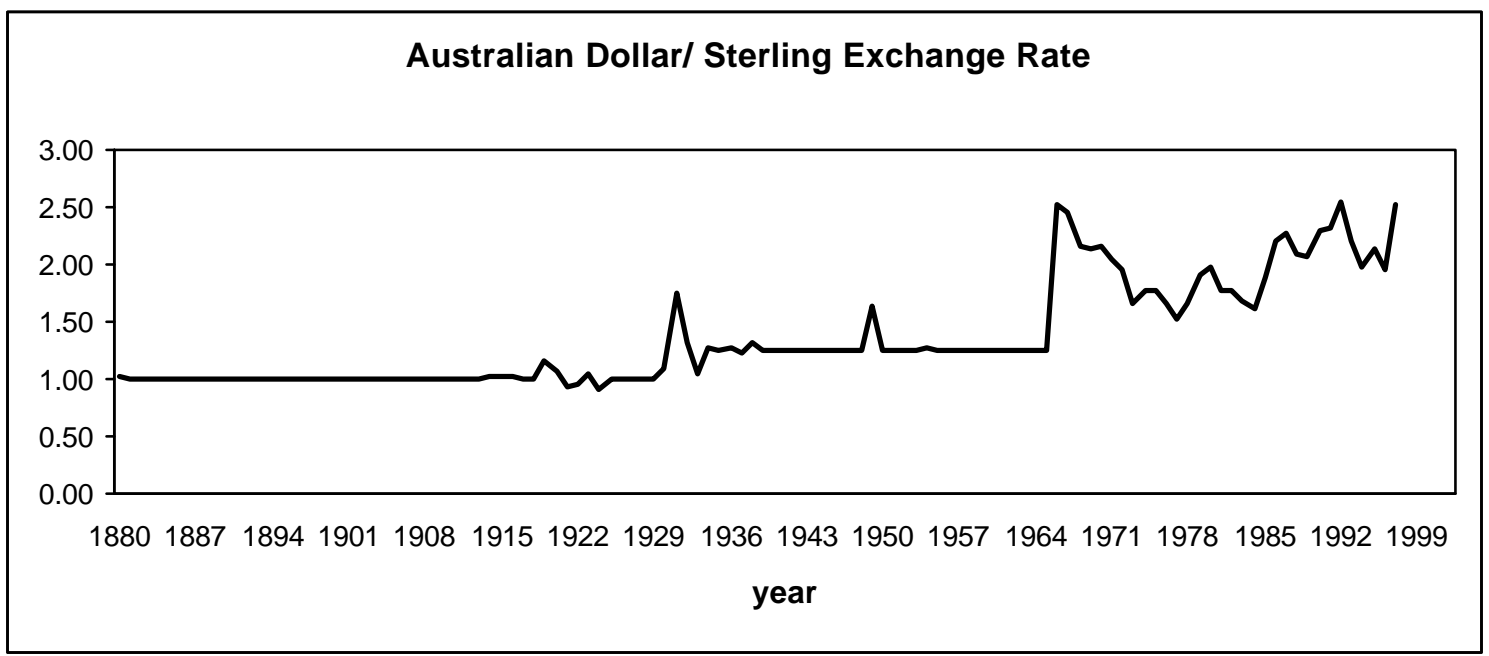

Source: Global Financial Database.

Figure 4: Non resident purchases of New Issues by Currency of Denomination, Canada, 1953-1990

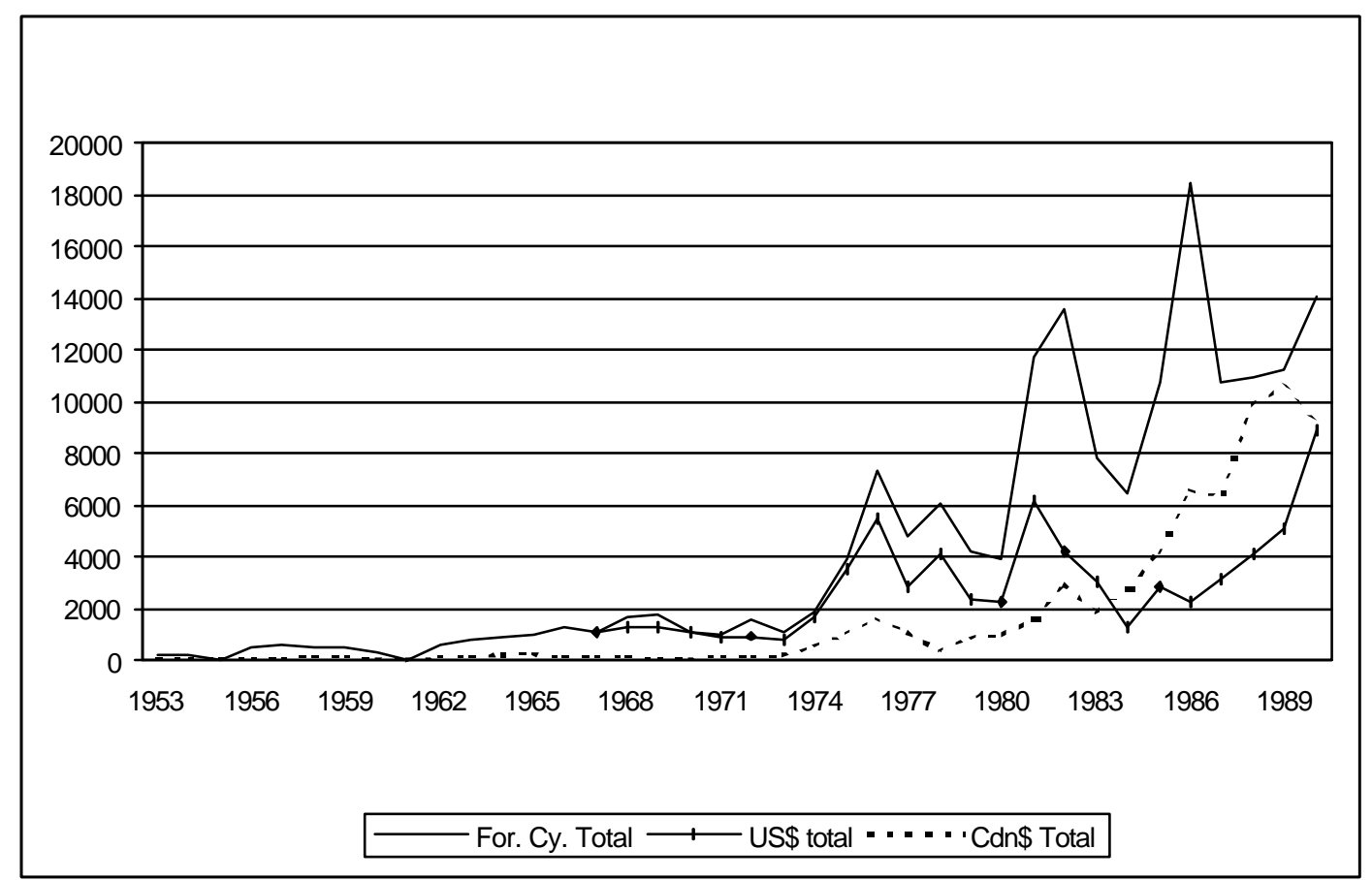

Source: Statistics Canada. 
Figure 5: Australia and United States, Exchange Rates 1950-2000.

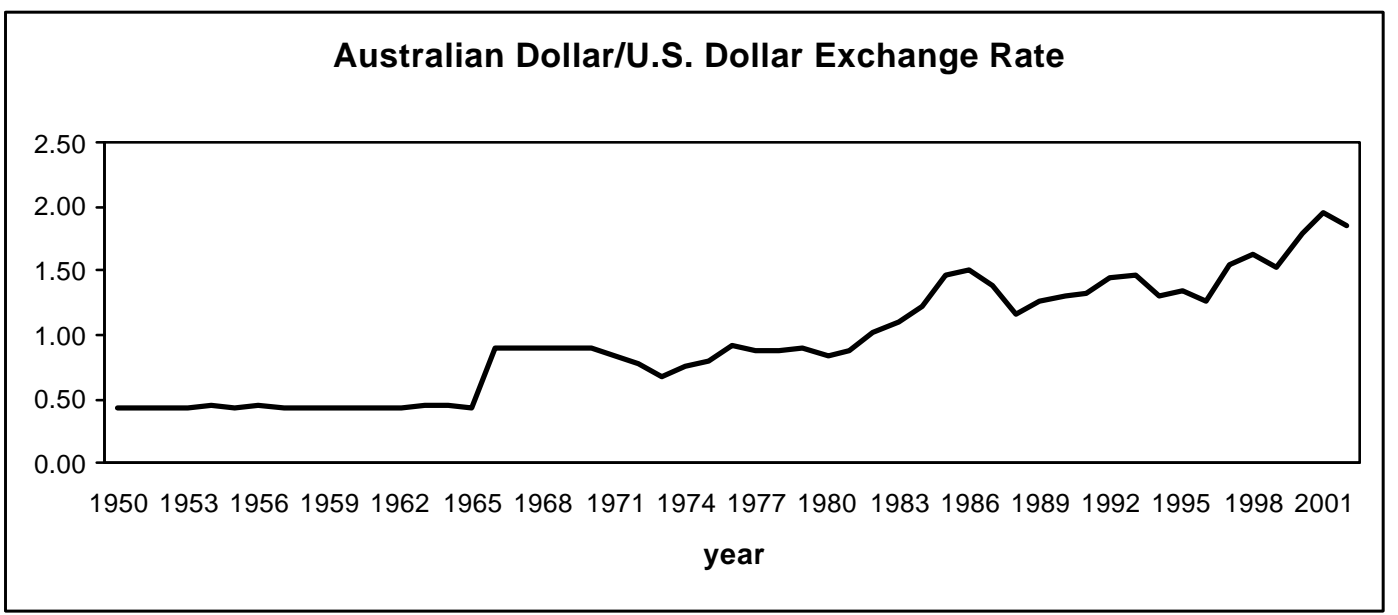

Source: Global Financial Database.

Figure 6: New Zealand and United States Exchange Rates 1950-2000.

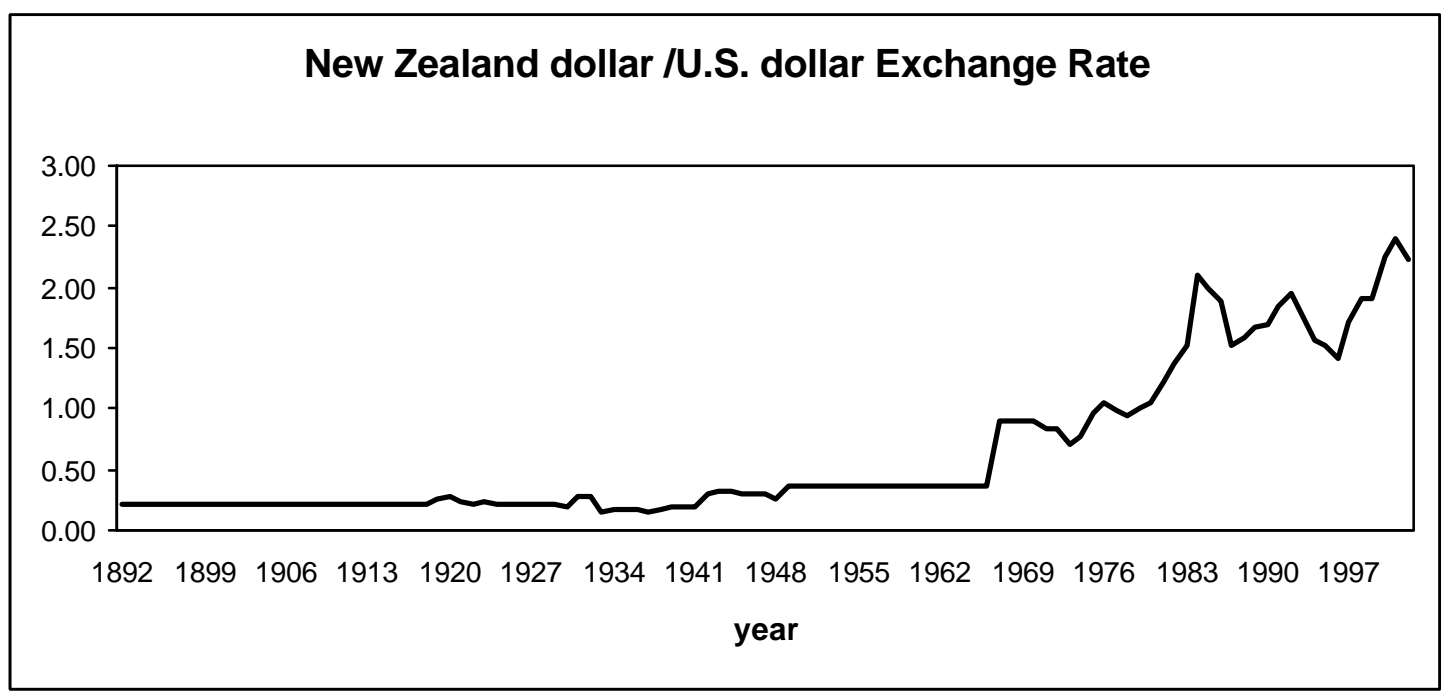

Source: Global Financial Database. 
Figure 7: Percentage of Internal NZ\$ Debt Held by Foreigners, New Zealand, 19892001.

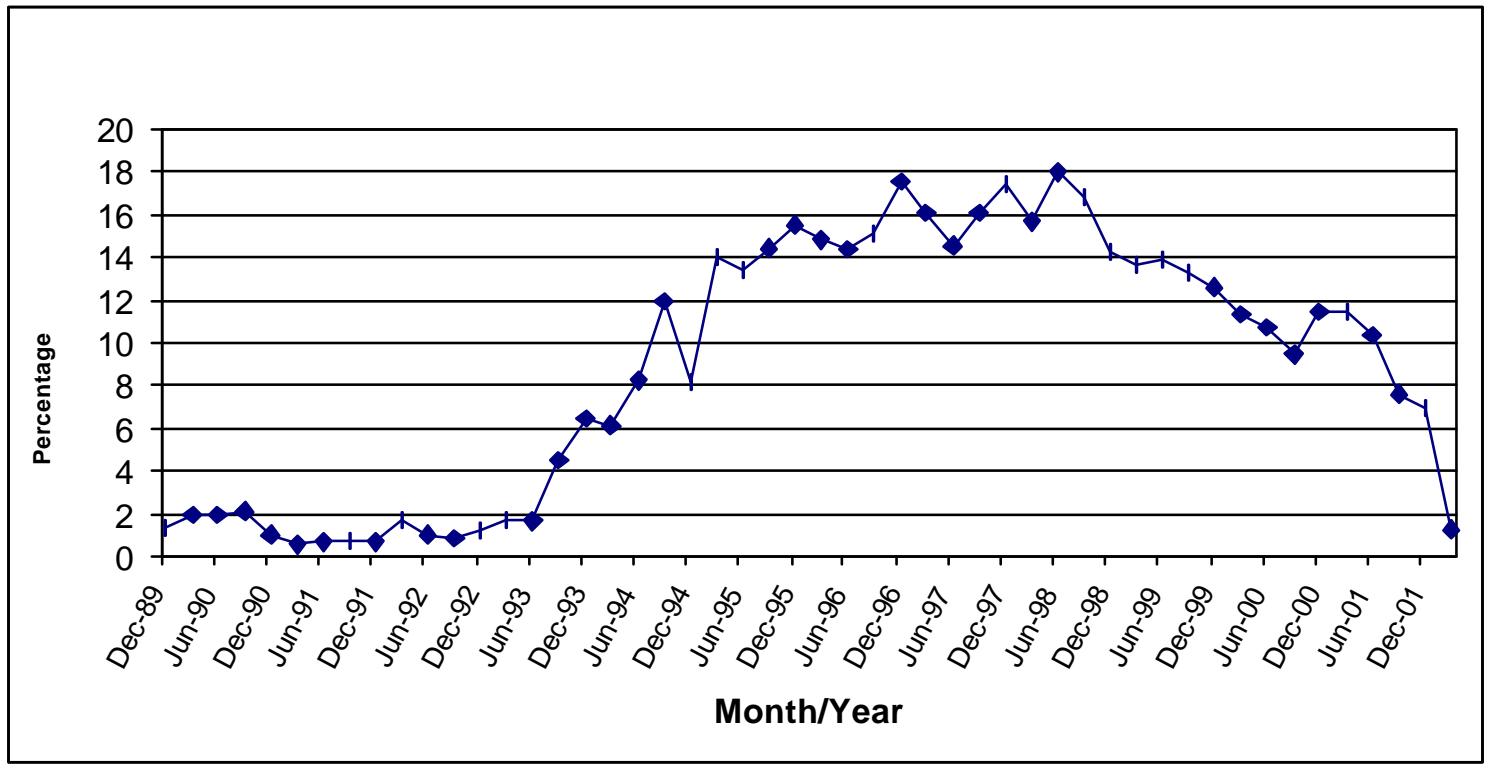

Source: Reserve Bank of New Zealand.

Figure 8: Average Maturity of Marketable National Government Debt in South Africa, 1996-2001

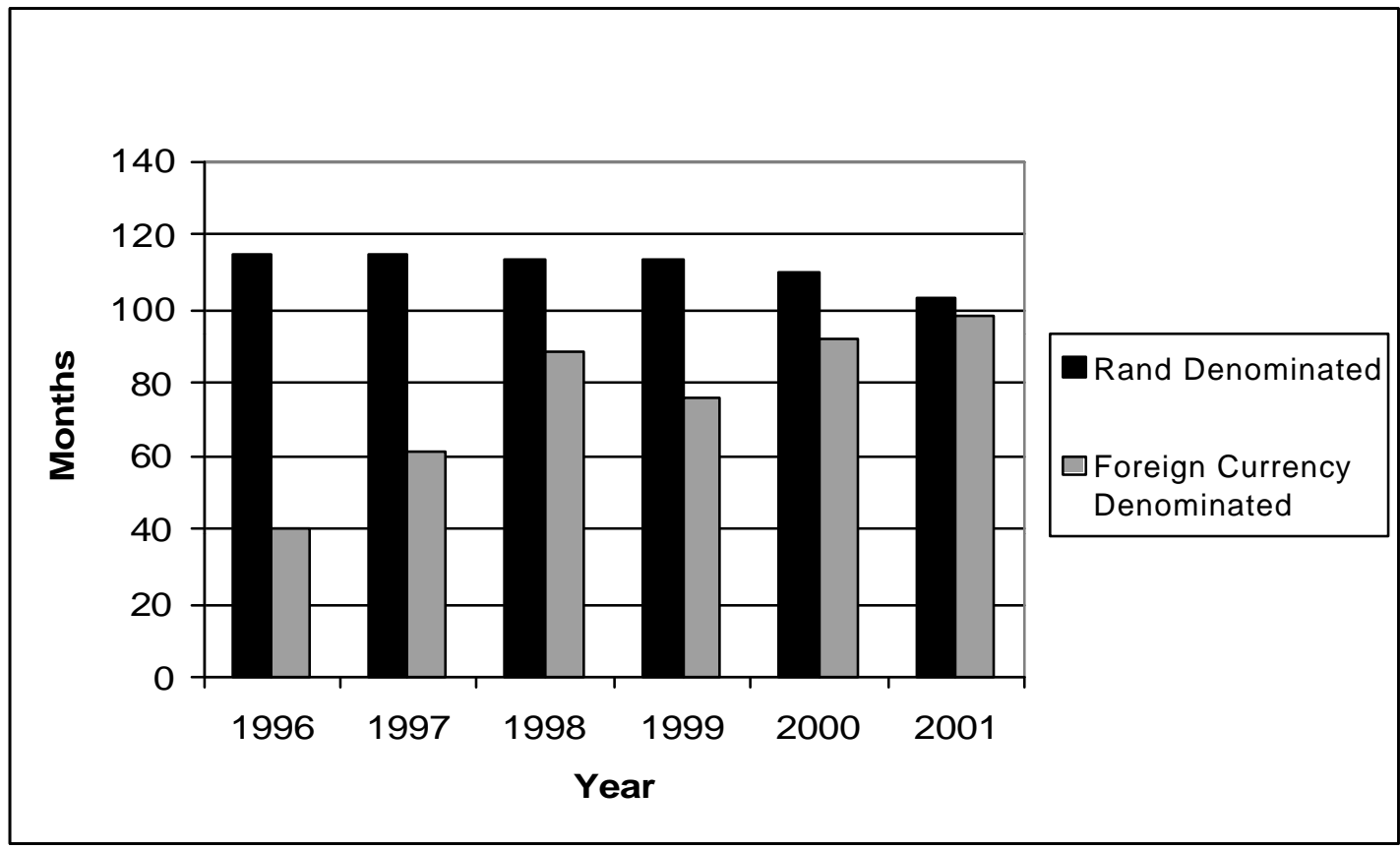

Source: South African Reserve Bank. 
Figure 9: Debt Denominated in Rand as a Percentage of All Debt Payable to Foreigners, 1994-2001

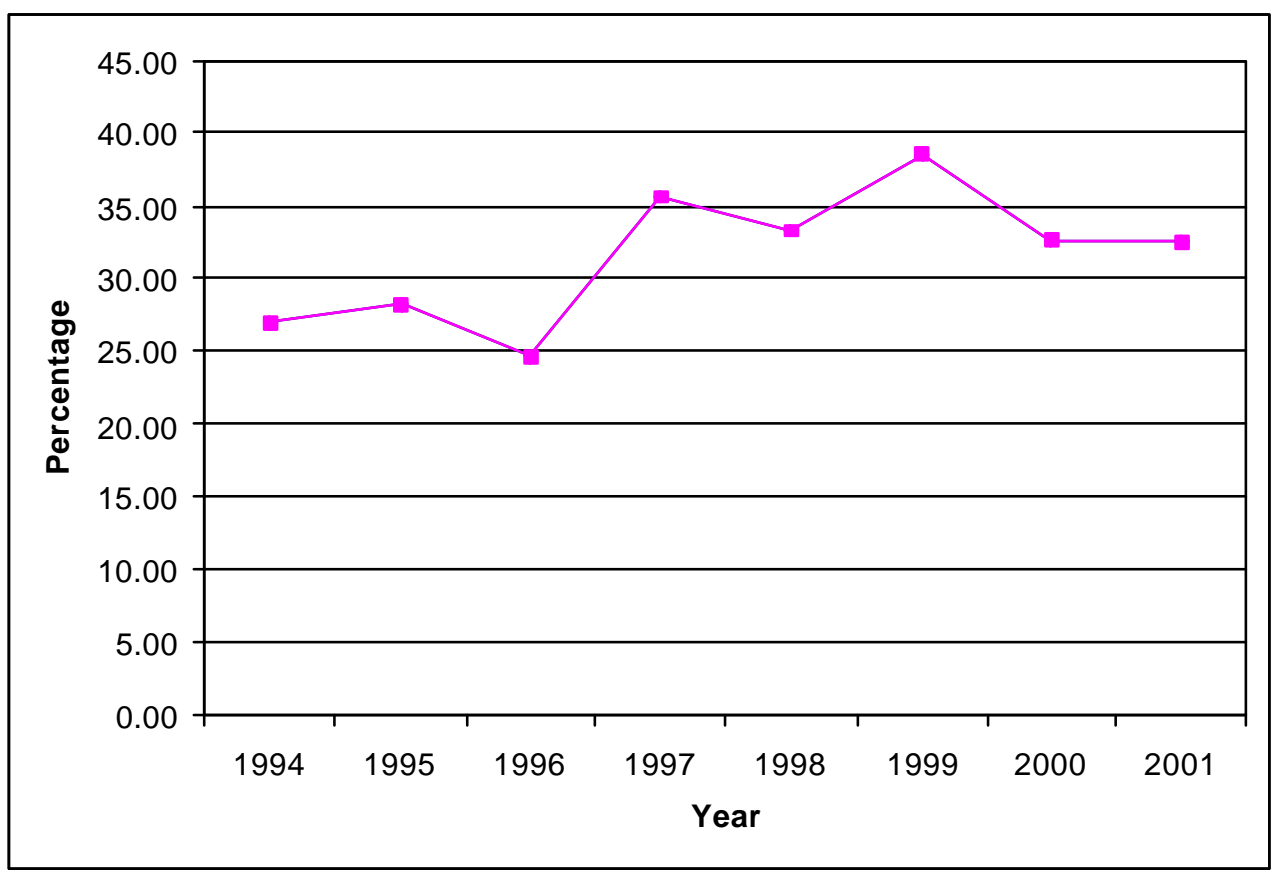


